spectrometry (MALDI). The authors speculate that MALDI will, in the not too distant future, replace gel electrophoresis in the analysis of DNA sequencing reactions.

This modestly priced book provides the molecular biologist with a wealth of current information on a wide variety of essential techniques. I look forward to the publication of volume 2 in this series, later this year.

JOHN MAULE MRC Human Genetics Unit, Western General Hospital, Edinburgh, EH4 $2 X U$

\section{Manipulating the Mouse Embryo. A Laboratory Manual, 2nd Edition. By Brigid Hogan, Rosa Beddington, Frank Costantini and Elizabeth LACY. Cold Spring Harbor Laboratory Press 1994, 497 pages. Price \$95. ISBN 0-87969-384-3.}

Before I opened the second edition of this classic laboratory manual I could tell that it had changed in two respects. It was bigger than the 1986 edition and it had gained a fourth author, Rosa Beddington. Once inside I could see that it had grown by about $50 \%$ (from 332 to 497 pages), several new colour figures and many new references had been added. About 800 references are cited, just over half of which were published after 1986 and so have been added since the last edition. Not surprisingly, the successful format of the first edition has been retained. The mouse linkage map has been omitted from the appendices, presumably because it dates so quickly. Otherwise, most of the first edition has been retained and expanded and the finished product is, as before, excellent.

Following an 18 page historical overview of mouse developmental genetics and embryology and an expanded summary of mouse development (now 93 rather than 59 pages), the book is divided into eight technical sections plus three appendices (recipes for buffers and solutions, sources of information and a list of suppliers), a reading list, a short glossary of the mouse genome and an index. The technical sections cover establishing a mouse colony; recovery, culture and transfer of embryos and germ cells; manipulation of preimplantation embryos; production of transgenic mice; embryonic stem cells; analysis of transgenic mice; visualising genes and gene products; media and culture conditions required for eggs, embryos, primordial germ cells and teratocarcinoma cells.

Rosa Beddington's influence can be seen in the expanded sections on gastrulation, fate maps and organogenesis in the revised Summary of Mouse Development. There are several new illustrations including an annotated diagram of development from fertilisation to term, colour diagrams of mouse development from $4 \frac{1}{2}$ to $8 \frac{1}{2} \mathrm{~d}$, epiblast fate maps, gene expression in the primitive streak and antero-posterior expression of Hox genes. The section that, in the first edition, was entitled Introduction of new Genetic Information into the Developing Mouse Embryo has been replaced by two new sections: In Vitro Manipulations of Preimplantation Embryos and Production of Transgenic Mice. The section on embryonic stem cells has increased from 14 to 38 pages and a 34 page section on Analysis of Transgenic Mice has been added. Despite the relocation of some of its original text (e.g. karyotype analysis) to Analysis of Transgenic Mice, the section on techniques for visualizing genes and gene products has more than doubled in length (now 60 pages) to accommodate descriptions of immunohistochemistry, whole mount in situ hybridization and lac- $Z$ staining.

There are several other books that cover techniques for manipulating mouse embryos. For example, those edited by Monk (1987), Copp \& Cockcroft (1990) and Wasserman \& dePamphilis (1993) are all excellent multi-author volumes that can be recommended. Most labs could probably make good use of all these technical manuals but if I could only have one of them Hogan, Beddington, Costantini and Lacy would be my first choice. It is more than a compilation of essential protocols, it is a well-balanced textbook encompassing both theoretical and practical aspects of modern mouse development biology. My recommendation is simple - if you work with mouse embryos you will definitely need a copy of this superb book. It is also an excellent source of information for those who teach mouse developmental biology and so should be available in all university libraries. Unfortunately, if you live outside the USA you will have to be patient with your bookshop because they will probably have to order it directly from Cold Spring Harbor Laboratory Press.

\section{References}

Copp, A. J. and Cockcroft, D. L. (1990). Postimplantation mammalian embryos. A practical approach. IRL Press, Oxford.

Monk, M. (1987). Mammalian development. A practical approach. IRL Press, Oxford.

Wasserman, P. M. and dePamphilis, M. L. (1993). Guide to techniques in mouse development. Academic Press, San Diego \& London.

JOHN D. WEST

Department of Obstetrics \& Gynaecology Centre for Reproductive Biology University of Edinburgh

Cellular Receptors for Animal Viruses. Monograph 28. Edited by Eckard Wimmer. Cold Spring Harbor Laboratory Press 1994. Cloth. 600 pages. Price \$97. ISBN 0-87969-429-7.

This 600-page volume is a comprehensive review of the subject of viral attachment to host cell receptors. It contains published material up to September 1994. 